This is an open access article under the terms of the CC-BY 3.0 License.

Peer review method: Double-Blind

Date of acceptance: December 21, 2020

Date of publication: January 08,2021

Review article

DOI: https://www.doi.org/10.47305/JLIA2163111n

\title{
INTERNATIONAL LEGAL STANDARDS IN COMBATING CHILD ONLINE SEXUAL ABUSE AND EXPLOITATION
}

\author{
Bistra Netkova \\ University of Mother Theresa - Skopje, North Macedonia \\ ORCID iD: https://orcid.org/0000-0002-5925-1037 \\ bistra_nl@yahoo.com

\section{Ariana Qosaj Mustafa} \\ Riinvest International, Accredited Programmes for London School of Economics, \\ Riinvest College, Kosovo \\ ORCID iD: https://orcid.org/0000-0003-3344-1980 \\ ari.qosajmustafa@gmail.com
}

\begin{abstract}
The general international standards are being discussed in this article, as well as more relevant ones concerned with the problem of sexual exploitation and child abuse. Further, the article discusses a growing understanding of children's exposure to violence, strengthened commitments to secure their safety and protection, and significant international implementation efforts to mobilize support for prevention and response and to help change attitudes and behavior which condone violence against children. With the fast development of the internet and online social networks, the article ends with a conclusion in identifying criminal law benchmarks based on the previously identified general international standards.
\end{abstract}

Keywords: Child Rights; Sexual Exploitation; Abuse of Children; International Human Rights Standards; Online Exposure 


\section{INTRODUCTION}

Over recent years the protection of children from violence has evolved from a largely hidden and neglected topic into a growing global concern. Framed by international human rights standards, including the Convention on the Rights of the Child and its Protocols, and guided by the United Nations study on violence against children, there has been a growing understanding of children's exposure to violence, strengthened commitments to secure their safety and protection, and significant national implementation efforts to mobilize support for prevention and response and to help change attitudes and behavior which condone violence against children. However, the fast development of the internet and online social networks has added challenges in the protection of children from sexual violence and abuse that happens online or is instigated through the internet as pointed out by the Global Alliance against Child Sexual Abuse Online:

Every day, countless children around the world are sexually abused and exploited, and images and videos of the abuse are circulated. Already in 2005, an estimated one million child sexual abuse images were online. 50.000 new child abuse images are added each year. More than $70 \%$ of the reported images feature children below 10 years of age (Global Alliance 2020).

Child sexual abuse including online sexual abuse and exploitation is a particularly serious crime that has wide-ranging and serious life-long consequences for victims. In hurting children, these crimes also cause significant and long-term social harm (Communication from the Commission 2020). Therefore, it is paramount for governments to be in line with the fast-developing structures and to criminalize all forms of online sexual exploitation and abuse of children. To be able to do so certain international standards need to be followed and benchmarks to be developed. In the text below the general international standards are being explored, as well as, the more specific ones dealing with the issue of sexual exploitation and abuse of children, to finally identify criminal law benchmarks based on the previously identified general international standards.

\section{GENERAL INTERNATIONAL LEGAL STANDARDS IN COMBATING CHILD SEXUAL ABUSE AND EXPLOITATION ONLINE}

The Convention on the Rights of the Child (CRC) (UN CRC 1990) is the most comprehensive document on the rights of children. It is the Magna Carta for the protection of children's rights. The Convention sets forward several substantive rights and also gives directions implementation measures. The CRC is also significant because 
it enshrines, "for the first time in binding international law, the principles upon which adoption is based, viewed from the child's perspective" (Global Research Center 2007, 8). The CRC is primarily concerned with four aspects of children's rights (the four P's): participation by children in decisions affecting them; protection of children against discrimination and all forms of neglect and exploitation; prevention of harm to them; and provision of assistance to children for their basic needs (UN CRC 1990).

The CRC defines a child as "every human being below the age of eighteen years unless, under the law applicable to the child, the majority is attained earlier" (UN CRC 1990, Art. 1). The CRC does not specifically refer to online protection of children's rights, because the time of its making does not correspond with the time of the emergence of the world-wide-web. The Convention sets some general international standards on which any law, measure, or procedure should be based concerning sexual violence, exploitation, and abuse of children. Consequently, the general international standards based on the CRC are:

Rights of the child: All actions are undertaken concerning children and children victims of sexual violence shall be guided by applicable human rights standards and in particular by the principles of protection and respect for children's rights as set out in the CRC (CRC General Comment 6 2009, 12). State obligations under the CRC apply to each child within the State's territory and all other children subject to its jurisdiction. Therefore, the enjoyment of rights stipulated in the Convention is not limited to children who are citizens of a state but must also be available to all children irrespective of their nationality, immigration status, or statelessness (UN CRC 1990, Art. 40). The involvement of child victims in criminal activities shall not undermine their status as both a child and a victim, or their related rights to special protection (CRC General Comment 6 2005, 13).

Non-discrimination: Every child shall have, without discrimination of any kind as to race, sex, language, religion, ethnic or social origin, birth, or another status, including immigration status, the right to such measures of protection as are required by his or her status as a minor (UN CRC, Guidelines 2019, 13).

The best interest of the child: The Committee on the Rights of the Child has highlighted in Article 3(1), that the best interest of the child shall be a primary consideration in all actions concerning children, as one of the general principles of the Convention on the Rights of the Child, alongside Articles 2, 6 and 12 (CRC General Comment 14 2013, 9). The principle was first seen in the 1959 Declaration of the Rights of the Child, which uses it in Principle 2:

The child shall enjoy special protection and shall be given opportunities and facilities, by law and by other means, to enable him to develop physically, mentally, morally, spiritually, and socially in a healthy and normal manner and conditions of freedom and dignity. In the enactment of laws for this purpose, the best interests of the child shall be the paramount consideration (CRC General Comment 14 2013, 9). 
This means that in all actions concerning child victims of sexual violence, exploitation, and abuse, whether undertaken in drafting laws, or by public or private social welfare institutions, police, courts of law, administrative authorities, or legislative bodies, the best interests of the child shall be a primary consideration (UN CRC, Guidelines 2019, 17). Furthermore, in devising criminal legislation regarding sexual violence against children this principle shall be the guiding point.

Respect for the views of a child: A child victim who is capable of forming his or her views has the right to express those views freely in all matters affecting him or her. Respect for the views of the child will be maintained with the legal process, interim care and protection, and the identification and implementation of a durable solution. The views of the child victim shall be sought and given due weight by his or her age and maturity. The child shall be provided the opportunity to be heard in any judicial and administrative proceedings affecting him or her, either directly, or through a representative or an appropriate body, in a manner consistent with the procedural rules of national law (UN CRC Guidelines 2019, 17).

Right to information: Child victims shall be provided with accessible information regarding their situation and their rights, including protection mechanisms, other available services. Information shall be provided in a language that the child victim can understand. Also, this principle applies to the right of children to be informed of the dangers of using the internet and the ways of preserving their safety (CRV GC 12 2009, 9-136).

Right to confidentiality: All necessary measures shall be taken to protect the privacy and identity of child and children victims to ensure the safety and security of the children and children victims and his or her family. The name, address, and all other information that could lead to the identification of the child victim or his or her family members shall not be revealed to the public or media. Exceptions may be made in circumstances such as to facilitate the tracing of family members or otherwise secure the wellbeing and protection of the child, with the informed consent of the child (CRC General Comment 16 2013, 21-23).

Right to be protected: Child victims are entitled to special protection measures, both as victims and as children, following their specific rights and needs. The State shall protect and assist child victims and ensure their safety (CRC General Comment 16 2013, 22).

These general principles also help to capitalize on the potential of the online environment to promote children's learning and freedom of expression; to support children in accessing, receiving, and imparting information; and to protect them from harmful materials and information, from unlawful interference with their privacy or correspondence, and from situations where their honor and reputation may be at risk. 


\section{SPECIFIC INTERNATIONAL STANDARDS}

Having explored the overall general standards regarding the base of any national action, legislation policy, and measure, concerning sexual exploitation of children and abuse over the internet, there are more specific international standards that derive from the overall general human rights standards. The Rio de Janeiro Declaration and Call for Action to Prevent and Stop Sexual Exploitation of Children and Adolescents pledges for a more comprehensive and concerted global effort enhanced cooperation between different organizations and initiatives are particularly important in the light of challenges related to the information society (Rio Declaration 2008). In the face of the growing threat of cybercrime, common efforts to strengthen legislative frameworks, criminal justice capacities, international cooperation, and public/private cooperation are required and are regarded as the primary principles in fighting these crimes.

The CRC and its Optional Protocols, notably the Protocol on the sale of children, child prostitution, and child pornography (OPSC 2002, 1), provide important guidance for the realization of children's rights concerning sexual exploitation and abuse over the internet. They call for all measures, including legislative, policy, and educational initiatives, to be guided by the best interests of the child; to respect and support children's growing autonomy and agency, and to protect children from violence and discrimination.

The CRC does not specifically criminalize child sexual abuse images, although a prohibition on this material is implicit in, for example, the child's right to protection against "arbitrary or unlawful interference with his or her privacy" and to "unlawful attacks on his or her honor and reputation" under Article 16 (UN CRC 1990). However, in recent years, the Committee on the Rights of the Child has given increasing attention to ICTs and the internet in its concluding observations to periodic reports on the CRC and the adopted Optional Protocol to the Convention on the Rights of the Child on the sale of children, child prostitution and child pornography (OPSC) (CRC Concluding observations 2013, 11). Its recommendations have highlighted crucial areas requiring further efforts, including the adoption of "a national coordinating framework to address all forms of violence against children, including on the internet"; a passage of comprehensive legislation "to criminalize all forms of child pornography and sexual exploitation of children on the internet" and the "solicitation of children for sexual purposes and accessing child pornography utilizing information and communication technology"; and measures to prevent publication and dissemination of pornographic material concerning children through surveillance mechanisms to automatically block offending internet service providers (ISPs) and other media, and taking prompt steps to establish an authority for internet safety, ISP licensing and checks for content harmful to children (CRC Concluding Observations 2014, 14). 
The Committee's Day of General Discussion on 'Digital media and child rights', held in September 2014, contributed to further broadening the scope of the Committee's reflections in this area and to the development of rights-based strategies to maximize online opportunities for children while protecting them from risks and possible harm (CRC 2014). Further, the OPSC also provides important guidance in this respect. Article 1 of the OPSC requires States Parties to 'prohibit the sale of children, child prostitution and child pornography,' where child pornography is, "(...) any representation, by whatever means, of a child engaged in real or simulated explicit sexual activities or any representation of the sexual parts of a child for primarily sexual purposes" (OPSC 2002, Art. 1). Article 3 requires that each State party ensure that, as a minimum, "[p]roducing, distributing, disseminating, importing, exporting, offering, selling or possessing (...) child pornography" is fully covered under its criminal or penal law, whether such offenses are committed domestically or transnationally or on an individual or organized basis (OPSC 2002).

The OPSC requires that countries criminalize possession with the intent to distribute, disseminate, and sell. The OPSC also considers the obligations of States Parties to fight impunity. Article 4 requires each State party to "take such measures as may be necessary to establish its jurisdiction over the offenses (...) when the offenses are committed in its territory or onboard a ship or aircraft registered in that State" (OPSC 2002).

Given the global nature of the internet and the international dimension that characterizes much online violence, exploitation, and abuse, Article 6 calls on States Parties to "afford one another the greatest measure of assistance in connection with investigations or criminal or extradition proceedings (...) including assistance in obtaining evidence at their disposal necessary for the proceedings" (OPSC 2002).

Under Article 9, States Parties are required to "adopt or strengthen, implement and disseminate laws, administrative measures, social policies, and programs to prevent the offenses it refers to" (OPSC 2002). Paying special attention to especially vulnerable children is another concern expressed (OPSC 2002, Art. 6) as well as, "awareness in the public at large, including children, through information by all appropriate means, education and training, about the preventive measures and harmful effects of the offenses referred to in the present Protocol" (OPSC 2002, Art. 6). Article 9 also addresses the important issue of rehabilitation and compensation for children who have fallen victim to offenses involving images of child sexual abuse (OPSC 2002).

To add another instrument to the list, the Istanbul Convention which is an important novel addition to the international standards to fight sexual violence against women and children? It is important to point out that the Istanbul Convention requires States Parties to ensure that gender-based violence against women may be recognized as a form of persecution, encompassing girls under eighteen (CoE CETS 201, 2011). This is the first time that gender-related persecution is explicitly mentioned in an 
international convention. The Istanbul Convention is a tool for the inclusion of a gender perspective into all measures to prevent and combat violence against children. The Convention requires States Parties to adopt legislative and practical measures to prevent and combat violence against women and girls, as well as, to coordinate measures through comprehensive policies (CoE CETS 201, 2011). It establishes an obligation to introduce gender-sensitive procedures, guidelines, and support services in the asylum process. It requires, among other things, that children are afforded adequate protection and support as victims and witnesses of domestic violence (CoE CETS 201, 2011).

\section{INTERNATIONAL STANDARDS TRANSLATED TO CRIMINAL LAW BENCHMARKS}

The Rio Declaration and Call for Action to Prevent and Stop Sexual Exploitation of Children and Adolescents calls governments to ratify the OPSC, the Lanzarote and Budapest Conventions and to: "Define, prohibit and criminalize, following existing international human rights standards, all acts of sexual exploitation of children and adolescents in their jurisdiction, irrespective of any stage of consent or marriage or cultural practice, even when the adult is unaware of the child's age" (Rio Declaration 2008, 8).

The Council of Europe Convention on the Protection of Children against Sexual Exploitation and Sexual Abuse (Lanzarote Convention) is the first treaty to address children's protection from sexual violence in the face of challenges presented by technological developments, and to identify as an offense the solicitation of children for sexual purposes through ICTs, often known as 'grooming'. The Council of Europe Convention on Cybercrime (Budapest Convention) criminalizes offenses against and through computer systems, including child pornography; provides law enforcement with effective means to investigate cybercrime and secure electronic evidence, and offers a framework for international police and judicial cooperation in computer-related cases involving crimes against children. Both conventions can be adhered to by states from other regions, which is useful for having in mind the unlimited character of the internet.

The Lanzarote Convention aims to eradicate all sexual exploitation and abuse of children. It requires the criminalization of sexual exploitation and abuse, the criminal prosecution of perpetrators, and effective remedies and support for child victims (CoE CETS 201, 2007). The Convention defines sexual exploitation of children as a criminal offense. It provides effective, proportionate, and dissuasive sanctions against prostitution, pornography, grooming, and sex-tourism and also covers sexual abuse. The Convention calls on state authorities; civil society and the private sector need to join forces to prevent sexual exploitation and sexual abuse, to protect the victims, and to end impunity. In this respect, the Lanzarote Convention insists on both national and international cooperation is a facto sine qua non, for effective eradication of online sexual exploitation and abuse of children and protection of victims. 
The Convention also includes a monitoring mechanism, in the form of the Lanzarote Committee. This Committee as a monitoring body assesses the situation in the countries to identify challenges or obstacles to the effective implementation of the Convention and also effectively functions as an observatory of good practices and allows capacity building. Because the sexual exploitation of children over the internet is predominately a gender influenced practice, the Lanzarote Convention even though it covers all children without any particular focus on girls or boys, the Committee has requested the States Parties to specify how measures for victims and offenders take into account gender-specific requirements (AS/Soc (2014) OJ 01 rev 2014, 7). The results of this monitoring work will therefore serve to cast some light on the measures needed to prevent girls from becoming victims of sexual exploitation and abuse (AS/Soc (2014) OJ 01 rev 2014, 7).

Both treaties combined contain a comprehensive set of measures to address sexual exploitation and sexual abuse of children both in the online and offline environment. Widely applied, they aim to contribute to global harmonization of criminal law, and this, in turn, is supporting the facilitation of international operational cooperation as underlined by Interpol and the Virtual Global Taskforce (AS/Soc (2014) OJ 01 rev 2014, 9) with the ultimate goal of eradication of online sexual exploitation and abuse of children.

Accordingly, Interpol reported on a follow-up initiative addressing online sexual abuse of children via delivering on operations targeting organized crime networks, behind cases of 'sextortion' globally. In 2014, for example, an operation organized and delivered by Interpol has resulted in the arrest of 58 persons that were also involved in the case of the Scottish teenager Daniel Perry, 17 years old that committed suicide in Scotland in 2013, after being a victim of online blackmailing. The operation as a first of its kind was a joint effort between Interpol Digital Crime Centre (IDCC), the Hong Kong Police Force and Singapore Police Force as well as of the Philippines National Police that led to the identification of almost 195 persons working for organized crime groups operating from the Philippines. In close cooperation with Scottish police, US Homeland Security Investigations the operation resulted in the identification of sextortion victims including in the UK, the United States and Indonesia, and the Philippines (Interpol 2014). Both, the Lanzarote and the Budapest Conventions represent international standards that may serve as benchmarks and may support the harmonization of criminal law aimed at protecting children against sexual exploitation and abuse (CoE ETC 185 2001). Article 3 of the Lanzarote Convention stipulates that the "sexual exploitation and sexual abuse of children" shall include the behavior as referred to in Articles 18 to 23 of this Convention. The Budapest Convention covers child pornography in Article 9. Therefore, the Article has shown how the use of international child rights standards work has led to the steady and vast number of criminal law benchmarks to be fulfilled as minimal standards for countries within the EU and beyond. 
The analysis uses these articles to show the overall agreed minimum international standards for the criminalization of sexual exploitation and abuse of children over the internet. The Directive on combating sexual abuse, sexual exploitation of children and child pornography on which the European Parliament and the Council reached an agreement in June 2011 is another detailed document treating sexual exploitation and abuse of children over the internet (2011/92/EU). It states that the Council of Europe Convention on the Protection of Children against Sexual Exploitation and Sexual Abuse arguably constitutes the highest international standard for protecting children against sexual abuse and exploitation (COE ETC 185 2001). The Directive is complementary to both, the Lanzarote and Budapest Conventions.

\section{CONCLUSION}

The CRC in its time of making and adoption did not consider the fast-growing development of the World Wide Web and its wider use as a threat to sexual exploitation and child abuse. Accordingly, it did not account initially for the online protection of children's rights, because the time of its making did not correspond with the time of the emergence. However, in recent years, the Committee on the Rights of the Child has given increasing attention to ICTs and the internet in its concluding observations to periodic reports on the CRC, by requiring states to conduct a set of measures within their national responses in responding to all forms of violence against children, including on the internet as well as provide for legislation that would criminalize various forms of child pornography and sexual exploitation of children on the internet, by halting the solicitation of children online for sexual exploitation and other forms of child abuse. Furthermore, these international child rights standards have overall affected the rise in the making and adoption of the so-called Lanzarote and the Budapest Conventions that represent international standards serving as criminal law benchmarks and support the harmonization of criminal law aimed at protection of children against sexual exploitation and abuse online. In ending, the analysis has shown how the use of international child rights standards work has led to the rise of a vast number of criminal law benchmarks to be fulfilled as minimal standards for countries within the European Union and globally. Both treaties combined contain a comprehensive set of measures to address sexual exploitation and sexual abuse of children both in the online and offline environment. Widely applied, they aim to contribute to global harmonization of criminal law which in turn will facilitate international operational cooperation including the Interpol as reinforced, with the ultimate goal of eradication of online sexual exploitation and abuse of children.

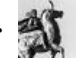




\section{REFERENCES}

1. Communication from the Commission to the European Parliament, the Council, the European Economic, and Social Committee, and the Committee of the Regions EU Strategy for a More Effective Fight Against Child Sexual Abuse, COM/2020/607 final, (2020), at https://eur-lex.europa.eu/legalcontent/EN/TXT/?uri=COM:2020:607:FIN. See also: https://ec.europa.eu/homeaffairs/sites/homeaffairs/files/what-we-do/policies/european-agendasecurity/20200724 com-2020-607-commission-communication en.pdf (Accessed November 2020).

2. Council of Europe Convention on preventing and combating violence against women and domestic violence, CETS No. 210, (2011), at https://www.coe.int/en/web/conventions/full-list/-/conventions/treaty/210 (Accessed December 2020).

3. Council of Europe Convention on the Protection of Children against Sexual Exploitation and Sexual Abuse (Lanzarote Convention), CETS No. 201, (2007), at https://rm.coe.int/1680084822 (Accessed November 2020).

4. Council of Europe, Convention on Cybercrime, ETS No.185 (2001), at:

5. https://www.coe.int/en/web/conventions/full-list/-/conventions/treaty/185 (Accessed November 2020).

6. Council of Europe, Committee on Social Affairs, Health and Sustainable Development, Minutes of the Joint meeting of the PACE Network of Contact Parliamentarians to stop sexual violence against children and the Parliamentary Network "Women Free from Violence" on "Sexual exploitation of girls", held in Strasbourg on Wednesday, 29 January 2014, at https://doczz.biz.tr/doc/197292/minutes---conseil-de-l-europe (Accessed November 2020).

7. EU DIRECTIVE 2011/92/EU OF THE EUROPEAN PARLIAMENT AND OF THE COUNCIL of 13 December 2011 on combating the sexual abuse and sexual exploitation of children and child pornography, and replacing Council Framework Decision 2004/68/JHA (2011), https://srsg.violenceagainstchildren.org/document/2011-92eu 917\#sthash.Lha4Mqlp.dpuf (Accessed November 2020).

8. Global Legal Research Center, "Children's Rights: International Laws, Argentina, Australia, Brazil, Canada, China, France, Germany, Greece, Iran, Israel, Japan, Lebanon, Mexico, Nicaragua, Russia, and the United Kingdom" (August 2007), the Law Library of Congress.

9. Global Alliance against Child Sexual Abuse Online, http://ec.europa.eu/dgs/home-affairs/what-we-do/policies/organized-crime-and- 
human-trafficking/global-alliance-against-child-abuse/index en.htm (Accessed December 2020).

10. Interpol, Gaining Perspectives on Labor Trafficking, 2014, https://securityrisk1.wordpress.com/tag/interpol/ (Accessed December 2020).

11. Independent Experts for the United Nations, Study on violence against children (A/61/299), para.1, (2006), at https://reliefweb.int/report/world/reportindependent-expert-united-nations-study-violence-against-children-a61299 (Accessed December 2020).

12. Media Report, Interpol Coordinated Operation Strikes Back at Sextortion Networks, 2014. Available at https://www.interpol.int/News-andEvents/News/2014/INTERPOL-coordinated-operation-strikes-back-at-sextortionnetworks\#: :text=MANILA\%2C\%20Philippines\%20\%2D\%20An\%20INTERPOL\%2D harassed\%20Scottish\%20teenager\%20Daniel\%20Perry (Accessed December 2020).

13. Rio de Janeiro Declaration and Call for Action to Prevent and Stop Sexual Exploitation of Children and Adolescents, https://srsg.violenceagainstchildren.org/document/ 908 (Accessed November 2020).

14. United Nations Convention on the Rights of the Child, Adopted and opened for signature, ratification, and accession by General Assembly resolution 44/25 of 20 November 1989 entry into force 2 September 1990, following Article 49, at https://www.ohchr.org/en/professionalinterest/pages/crc.aspx (Accessed November 2020).

15. United Nations, Committee on the Rights of the Children General Comment No. 14 (2013) on the right of the child to have his or her best interests taken as a primary consideration (Art. 3, para. 1)*(2013), at https://www.refworld.org/docid/51a84b5e4.html (Accessed November 2020).

16. United Nations, Committee on the Rights of the Child, GENERAL COMMENT NO. 12 (2009) The right of the child to be heard CRC/C/GC/12 20 July 2009, at https://www.refworld.org/docid/4ae562c52.html (Accessed December 2020).

17. United Nations, Committee on the Rights of the Child, General Comment No. 6 (2005), TREATMENT OF UNACCOMPANIED AND SEPARATED CHILDREN OUTSIDE THEIR COUNTRY OF ORIGIN at https://www.refworld.org/docid/42dd174b4.html (Accessed November 2020).

18. United Nations, Committee on the CRC, concluding observations on the combined third and fourth periodic reports of China, adopted by the Committee at its sixty-fourth session (16 September-4 October 2013), 29 October 2013. $\mathrm{CRC} / \mathrm{C} / \mathrm{CHN} / \mathrm{CO} / 3-4$, and the Optional Protocol to the Convention on the Rights of the Child on the sale of children, child prostitution and child pornography, (31 January 2014). CRC/C/OPSC/PRT/CO/1, at 
http://docstore.ohchr.org/SelfServices/FilesHandler.ashx?enc=6QkG1d\%2FPPRiC AqhKb7yhso23wCwLcl6mikolpecekJiKxokT9PZd\%2BAluwnAS9cTQ8odgT3SN5r8b 2fwEGfzcssJ8eKxAFqJbvyE3s8JRY4Uw714nkOnElqyaQajNCXsj (Accessed November 2020).

19. United Nations, COMMITTEE ON THE RIGHTS OF THE CHILD REPORT OF THE 2014 DAY OF GENERAL DISCUSSION "Digital media and children's rights" (2014), http://www.ohchr.org/Documents/HRBodies/CRC/Discussions/2014/DGD report. pdf (Accessed November 2020).

20. United Nations, CRC, Concluding observations on the report submitted by Portugal under article 12, paragraph 1, of the Optional Protocol to the Convention on the Rights of the Child on the sale of children, child prostitution and child pornography, (31 January 2014), at https://www.refworld.org/docid/52f89b184.html (Accessed November 2012).

21. United Nations, Optional Protocol to the Convention on the Rights of the Child on the sale of children, child prostitution and child pornography, (2000), adopted and opened for signature, ratification, and accession by General Assembly Resolution A/RES/54/263 of 25 May 2000, entered into force on 18 January 2002, at https://www.ohchr.org/en/professionalinterest/pages/opsccrc.aspx (Accessed November 2020).

22. United Nations Convention on the Rights of Child Guidelines regarding the implementation of the Optional Protocol to the Convention on the Rights of the Child on the sale of children, child prostitution and child pornography, 2019, at https://www.ohchr.org/Documents/HRBodies/CRC/CRC.C.156 OPSC\%20Guidelin es.pdf (Accessed November 2020). 